Original Contribution

\title{
CARACTERISTICS OF PRODUCTIVE AND QUALITY POSSIBILITIES OF INTRODUCED RICE VARIETIES GROWN UNDER CONDITIONS OF SOUTHERN BULGARIA
}

\author{
Sv. Tosheva*, M. Sabeva \\ Institute of Plant Genetic Resources" K. Malkov", Sadovo, Bulgaria
}

\begin{abstract}
The study was conducted during the period 2013-2014. Three Turkish (Denep, Efe, Gala) and four Italian (Baldo, Creso, Roma, Puma) rice variety used in the country are explored. During the growing season it is applied the standard agrotechnics of rice cultivation in Bulgaria.The samples were evaluated on morphological, biochemical and economic qualities according to international descriptors: vegetation period, paddy yield, length of panicle, weight of a panicle, mass of 1000 grains, total number grains in panicle, empty grains, crude protein, lysine. The indicators that are characterizing the productivity of varieties vary significantly at greater extent than those with quality. There are established positive correlations between the total number of grains in a panicle of rice production $(r=0.713)$, the weight of a panicle $(r=0.715)$ and the number of empty grains $(r=0.809)$ and negative with crude protein contents $(\mathrm{r}=-0.700)$. Radiated are varieties to be included in breeding programs as sources of valuable economics signs.
\end{abstract}

Key words: rice, varieties, yield, quality, correlations

\section{INTRODUCTION}

Rice as a basic and valuable food for man occupies a leading place among the cereals. According to some approximate data it provides $70-80 \%$ of the food used in the world for securing the calorie balance in the human body (1). According to the studies by the International Research Institute of Rice (IRRI), Philippines, the production is to increase by about $1 \%$ per year, not only because of the growing demands of the population for food but because of the unfavorable weather conditions (2).

The strategy of breeding programs is the creation of new rice varieties, where the ability for high yield will be combined with a larger number of properties that determine the quality. Variations in external conditions, the emergence of new pests and diseases, the introduction of new manufacturing technologies, the expansion of scientific knowledge, technical, personnel and material possibilities and many other factors influence the purposes of the selection. Therefore, breeders should not only have access to a

\footnotetext{
*Correspondence to: Svilena Tosheva, Institute of Plant Genetic Resources" K. Malkov"- 4122

Sadovo, 2 Druzhba St, Bulgaria, sv.tocheva@abv.bg
}

suitable vast range of genplasm but also should have access to the information necessary for it (3).

To enrich the genetic basis for breeding and production purposes it is required continual introduction of new lines and varieties from other researchers and countries $(4,5)$. With the extension of genplasm there reduces the risk of genetic damage that exists as a result of multiple use of varieties for different purposes in a given area $(6,7)$. The assessment of the value of a variety is mainly based on the morphological assessment of its biological and production characteristics. The high yield potential and good technical quality are the main characteristics of a rice variety to be recommended for production. In this particular matter of great importance is also their stability, i.e. the ability of the genotype in different agro-ecological conditions to preserve such values for those properties or to what extent the values could vary under the influence of the year.

It is necessary for the selection also researches of mutual influence of the structural elements of productivity on which it is made selection and correlation between them. The aim of the study is the assessment of 
TOSHEVA SV., et al.

introduced varieties of rice and establishment of the degree of variation of some morphological-biological and quality indicators and the requirements of correlations between them.

\section{MATERIAL AND METHODS}

The study was conducted during the period 2013 - 2014, at IPGR "K. Malkov "- Sadovo. There were investigated three Turkish varieties (Denep, Efe, Gala) and four Italian varieties (Baldo, Creso, Roma, Puma) of rice distributed in the production. For a standard it was used Osmandzhik 97 (Turkey), which was a standard also in Executive agency for variety testing, approbation and seed control (Bulgaria). The scheme of planting is based on the block method in four repetitions with vintage parcel size of $10 \mathrm{~m}^{2}$. During the growing season it is applied the standard agrotechnics of rice cultivation in Bulgaria.

Were examined the indicators: vegetation period $\left(\mathrm{X}_{1},\right)$ paddy yield $\left(\mathrm{X}_{2}\right)$, length of panicle $\left(X_{3}\right)$ weight of a panicle $\left(X_{4}\right)$ mass of 1000 grains $\left(\mathrm{X}_{5}\right)$, total number grains in panicle $\left(\mathrm{X}_{6}\right)$, empty grains $\left(\mathrm{X}_{7}\right)$, sterility $\left(\mathrm{X}_{8}\right)$ on Bioversity International, IRRI and WARDA (8) and lysine in the protein $\left(\mathrm{X}_{11}\right)$.

Paddy yield data are at $14 \%$ moisture. In the chemical analysis of grain the crude protein content $\left(\mathrm{X}_{9}\right)$ is determined by the Keldal method, and lysine $\left(\mathrm{X}_{10}\right)$ - colorimetric. The chemical score of protein $\left(\mathrm{X}_{12}\right)$ is calculated on the content of the limiting amino acid lysine (9).

For a more objective assessment of varieties as important indicators are used the statistical methods with the help of the software SPSS 13.0. The difference between the average of the options are assessed by test smallest permissible difference (LSD) at significance level of $5 \%$ GD. It was conducted a correlation analysis to establish statistically significant correlations between the studied indicators as it is accordingly noted the level of significance of the correlation coefficients.

\section{RESULTS AND DISCUSSIONS}

Table 1 shows the results for the average of the studied parameters in the introduced varieties of rice.

In terms of vegetation period and paddy yield rice all samples are shown to differ from the standard Osmandzhik 97.
The results of phenological observations show that the tested genotypes were characterized by average range early to medium long vegetation period according to the descriptive scale of Bioversity International (8). The Italian variety Puma has the shortest vegetation period and it ripens six days earlier than the standard.

Average for the period than most productive varieties are the Turkish Denep and Efe, as superior to the standard $17 \%$. All others have a lower paddy yield than Osmandzhik 97.

From the comparing analysis of received values obtained from the standard in terms of the length of panicle and mass of 1000 grains, it has been proven the differences in six varieties with the only exception Efe. Four of the introduced varieties have shown a greater weight of a panicle from the standard two less variety and variety Puma is of no difference.

Varieties Denep, Efe, Puma and Gala have a greater total number of grains in a panicle of the standard and Creso, Puma, Roma, Efe and Gala it exceeded the crude protein content in grain.

With the best quality of grain stands Gala. Only it proved to exceed the standard samples and the other samples of content of lysine in the protein and biological value of protein and its is of interest for selection when creating varieties with improved quality. From the results it is seen that only that variety differs from Osmandzhik 97 regarding all test parameters.

Higher productivity of varieties Denep and Efe is due to the great weight of the panicle and the total number of beans in it. In Denep this is accompanied by a long-stalked. Italian variety Puma combines precocity high in crude protein and lysine in the grain. The studies of such varieties should continue to focus on their technological characteristics and their reaction to certain agricultural methods. Other genotypes due to various positive properties that characterize them and may be interesting for further studies to be included in the new breeding programs.

The indicators that are characterizing the productivity of varieties vary significantly at greater extent than those with quality(Table 2). 
TOSHEVA SV., et al.

Table 1. Characterization of the varieties on economic and biochemical characteristics (average for period)

\begin{tabular}{|c|c|c|c|c|c|c|c|c|c|c|c|c|}
\hline \multirow{3}{*}{ Varieties } & \multicolumn{12}{|c|}{ Characteristics } \\
\hline & \multicolumn{2}{|c|}{$\begin{array}{l}\text { Vegetation } \\
\text { period, days }\end{array}$} & \multicolumn{2}{|c|}{$\begin{array}{c}\text { Paddy yield, } \\
\text { kg/ha }\end{array}$} & \multicolumn{2}{|c|}{$\begin{array}{c}\text { Panicle } \\
\text { length, } \\
\text { cm }\end{array}$} & \multicolumn{2}{|c|}{$\begin{array}{c}\text { Weight of a } \\
\text { panicle, } g\end{array}$} & \multicolumn{2}{|c|}{$\begin{array}{l}\text { Mass of } 1000 \\
\text { grains, } g\end{array}$} & \multicolumn{2}{|c|}{$\begin{array}{c}\text { Total } \\
\text { number } \\
\text { grains in } \\
\text { the } \\
\text { panicle }\end{array}$} \\
\hline & & $\pm \mathbf{D}$ & & $\pm \mathbf{D}$ & & $\pm \mathbf{D}$ & & $\pm \mathbf{D}$ & & $\pm \mathbf{D}$ & & $\pm \mathbf{D}$ \\
\hline $\begin{array}{c}\text { Osmandzhik } 97 \\
\text { St }\end{array}$ & 131 & & 9170 & & 15.4 & & 5.2 & & 36.6 & & 137 & \\
\hline Denep & 141 & $10^{*}$ & 10730 & $1560 *$ & 22.4 & $7 *$ & 5.8 & $0.6^{*}$ & 32.1 & $-4.5^{*}$ & 187 & $50^{*}$ \\
\hline Efe & 133 & 2 & 10480 & $1310^{*}$ & 15.4 & 0 & 6.4 & $1.2^{*}$ & 36.5 & 0 & 177 & $40^{*}$ \\
\hline Gala & 134 & $3 *$ & 8510 & $-660^{*}$ & 15.2 & -0.2 & 5.0 & $-0.3^{*}$ & 35.3 & $-1.3^{*}$ & 151 & $14^{*}$ \\
\hline Baldo & 131 & 0 & 8110 & $-1060 *$ & 18.0 & $2.6^{*}$ & 5.7 & $0.5^{*}$ & 43.8 & $7.2^{*}$ & 135 & - \\
\hline Creso & 128 & $-3^{*}$ & 8850 & $-320 *$ & 18.7 & $3.4^{*}$ & 3.9 & $-1.4^{*}$ & 35.8 & $-0.8 *$ & 108 & $29 *$ \\
\hline Roma & 135 & $3.5^{*}$ & 8290 & $-890^{*}$ & 18.7 & $3.4^{*}$ & 5.8 & $0.6^{*}$ & 42.2 & $5.6^{*}$ & 136 & - \\
\hline Puma & 125 & $-6^{*}$ & 8720 & $-450 *$ & 20.6 & $5.2^{*}$ & 5.4 & - & 35.6 & $-1.0^{*}$ & 166 & $29^{*}$ \\
\hline \multirow{3}{*}{ Varieties } & \multicolumn{12}{|c|}{ Characteristics } \\
\hline & \multicolumn{2}{|c|}{$\begin{array}{l}\text { Empty } \\
\text { grains, } \\
\text { number }\end{array}$} & \multicolumn{2}{|c|}{ Sterility, } & \multicolumn{2}{|c|}{$\begin{array}{c}\text { Grude } \\
\text { protein, \% }\end{array}$} & \multicolumn{2}{|c|}{ Lysin, \% } & \multicolumn{2}{|c|}{$\begin{array}{l}\text { Lysine in the } \\
\text { protein \% }\end{array}$} & \multicolumn{2}{|c|}{$\begin{array}{c}\text { Biologica } \\
\text { value of } \\
\text { protein }\end{array}$} \\
\hline & & $\pm \mathbf{D}$ & & $\pm \mathbf{D}$ & & $\pm \mathbf{D}$ & & $\pm \mathbf{D}$ & & $\pm \mathbf{D}$ & & $\pm \mathbf{D}$ \\
\hline $\begin{array}{c}\text { Osmandzhik } 97 \\
\text { St }\end{array}$ & 7.5 & - & 18.3 & - & 6.44 & & 0.23 & - & 3.57 & & 51 & - \\
\hline Denep & 12.5 & $5^{*}$ & 15.1 & - & 6.17 & $-0.27 *$ & 0.24 & - & 3.89 & - & 56 & - \\
\hline Efe & 12.0 & $4.5^{*}$ & 14.9 & - & 6.58 & $0.14^{*}$ & 0.24 & - & 3.65 & - & 52 & - \\
\hline Gala & 12.0 & $4.5^{*}$ & 12.6 & $-5.7^{*}$ & 6.50 & $0.06^{*}$ & 0.27 & 0.04 & 4.16 & $0.59^{*}$ & 59 & $* 8$ \\
\hline Baldo & 6.0 & $-1.5^{*}$ & 23.1 & $4.8^{*}$ & 6.47 & - & 0.25 & - & 3.87 & - & 55 & - \\
\hline Creso & 5.5 & $-2 *$ & 19.9 & - & 7.43 & $0.99 *$ & 0.29 & 0.06 & 3.9 & - & 56 & - \\
\hline Roma & 7.0 & - & 19.8 & - & 6.64 & $0.20 *$ & 0.23 & - & 3.47 & - & 50 & - \\
\hline Puma & 16.5 & $9^{*}$ & 10.1 & $-8.2^{*}$ & 6.67 & $0.23^{*}$ & 0.26 & 0.03 & 3.89 & - & 55 & - \\
\hline
\end{tabular}

Table 2. Variation in the characterization in studies of rice varieties (average for period)

\begin{tabular}{|c|c|c|c|c|c|c|}
\hline \begin{tabular}{c} 
Characteristics \\
\hline
\end{tabular} & Minimum & Maximum & Mean & $\begin{array}{c}\text { Std. } \\
\text { Error }\end{array}$ & $\begin{array}{c}\text { Std. } \\
\text { Deviation }\end{array}$ & $\begin{array}{c}\text { Coefficient } \\
\text { variation, \% }\end{array}$ \\
\hline $\begin{array}{c}\text { Vegetation period, } \\
\text { days }\end{array}$ & 125.00 & 141.00 & 132.19 & 1.68 & 4.77 & 3.61 \\
\hline $\begin{array}{c}\text { Paddy yield, } \\
\text { kg/ha }\end{array}$ & 8110.00 & 10725.00 & 9105.00 & 34.68 & 98.09 & 10.77 \\
\hline $\begin{array}{c}\text { Panicle length, } \\
\text { cm }\end{array}$ & 15.20 & 22.40 & 18.04 & 0.93 & 2.64 & 14.63 \\
\hline Weight of a panicle, g & 3.85 & 6.35 & 5.37 & 0.26 & 0.75 & 13.93 \\
\hline $\begin{array}{c}\text { Mass of 1000 grains, g } \\
\text { Total number grains in the } \\
\text { panicle }\end{array}$ & 32,10 & 43,75 & 37,21 & 1,35 & 3,83 & 10,29 \\
\hline $\begin{array}{c}\text { Empty grains, } \\
\text { number }\end{array}$ & 108,00 & 186,50 & 149,31 & 9,16 & 25,90 & 17,35 \\
\hline Sterility, & 10,50 & 23,1 & 16,76 & 1,48 & 4,21 & 39,75 \\
\hline $\begin{array}{c}\text { Grude protein, } \\
\text { \% }\end{array}$ & 6,17 & 7,43 & 6,61 & 0,13 & 0,36 & 25,13 \\
\hline $\begin{array}{c}\text { Lysin, } \\
\text { \% }\end{array}$ & 0,23 & 0,29 & 0,25 & 0,01 & 0,02 & 8,52 \\
\hline $\begin{array}{c}\text { Lysine in the protein } \\
\text { Biological value of protein }\end{array}$ & 3,47 & 4,16 & 3,80 & 0,08 & 0,22 & 5,36 \\
\hline
\end{tabular}


Of all analyzed signs the least varied vegetation period $(\mathrm{CV}=3.61 \%)$, followed by the crude protein content $(\mathrm{CV}=5.52 \%)$, biological value of protein $(\mathrm{CV}=5.73 \%)$, lysine in the protein $(\mathrm{CV}=5.84 \%)$ and lysine in the grain $(\mathrm{CV}=8.36 \%)$. This shows that the introduced varieties from Italy and Turkey during the two-year period show a high degree of adaptability in the environmental conditions of the Plovdiv region and thus preserve the grain quality.

The greatest variation is found in the number of empty grains $(\mathrm{CV}=39.75 \%)$ and sterility $(\mathrm{CV}=25.13 \%)$. All other parameters fall within the group of medium variable properties with the coefficient of variation from 10 to $20 \%$. The results of our comparative experiment confirmed findings made in the similar studies $(10,11)$.

On Table 3 there are presented correlations between some of the major structural elements of the production and biochemical parameters in the analyzed varieties. The indicator of total grain in a panicle correlated positively with paddy yield $(\mathrm{r}=0.713)$, the weight of a panicle $(\mathrm{r}=0.715)$, empty grains $(\mathrm{r}=0.809)$ at a level of statistical significance $\mathrm{GD}=5 \%$ and negative with crude protein content in grain $(\mathrm{r}$ $=-0.700)$. The weight of a panicle is proven negative correlation with crude protein $(\mathrm{r}=-0.745)$ and lysine in the grain $(\mathrm{r}=-0.798)$. Relationship with the same sign and is established between the number of empty grains and sterility $(r=-0.947)$.

Table 3. Correlation coefficients between quality characteristics

\begin{tabular}{|c|c|c|c|c|c|c|c|c|c|c|c|c|}
\hline $\begin{array}{c}\text { Charac } \\
\text { teristics }\end{array}$ & $\mathbf{X}_{\mathbf{1}}$ & $\mathbf{X}_{\mathbf{2}}$ & $\mathbf{X}_{\mathbf{3}}$ & $\mathbf{X}_{\mathbf{4}}$ & $\mathbf{X}_{\mathbf{5}}$ & $\mathbf{X}_{\mathbf{6}}$ & $\mathbf{X}_{\mathbf{7}}$ & $\mathbf{X}_{\mathbf{8}}$ & $\mathbf{X}_{\mathbf{9}}$ & $\mathbf{X}_{\mathbf{1 0}}$ & $\mathbf{X}_{\mathbf{1 1}}$ & $\mathbf{X}_{\mathbf{1 2}}$ \\
\hline $\mathbf{X}_{\mathbf{1}}$ & 1 & 0,509 & 0,098 & 0,396 & $-0,222$ & 0,442 & $-0,021$ & 0,065 & $-0,601$ & $-0,408$ & 0,007 & 0,046 \\
\hline $\mathbf{X}_{\mathbf{2}}$ & & 1 & 0,186 & 0,396 & $-0,672$ & $\underline{\mathbf{0 , 7 1 3}}$ & 0,391 & $-0,330$ & $-0,322$ & $-0,282$ & $-0,094$ & $-0,105$ \\
\hline $\mathbf{X}_{\mathbf{3}}$ & & 1 & 0,008 & $-0,221$ & 0,262 & 0,258 & $-0,108$ & $-0,049$ & 0,048 & 0,109 & 0,131 \\
\hline $\mathbf{X}_{\mathbf{4}}$ & & & & 1 & 0,215 & $\underline{\mathbf{0 , 7 1 5}}$ & 0,334 & $-0,106$ & $\underline{\mathbf{- 0 , 7 4 5}}$ & $\underline{\mathbf{- 0 , 7 9 8}}$ & $-0,414$ & $-0,437$ \\
\hline $\mathbf{X}_{\mathbf{5}}$ & & & & & 1 & $-0,484$ & $-0,584$ & 0,693 & 0,052 & $-0,252$ & $-0,405$ & $-0,402$ \\
\hline $\mathbf{X}_{\mathbf{6}}$ & & & & & 1 & $\underline{\mathbf{0 , 8 0 9}}$ & $-0,658$ & $\underline{\mathbf{- 0 , 7 0 0}}$ & $-0,413$ & 0,088 & 0,062 \\
\hline $\mathbf{X}_{\mathbf{7}}$ & & & & & & 1 & $\underline{\mathbf{- 0 , 9 4 7}}$ & $-0,376$ & $-0,015$ & 0,341 & 0,300 \\
\hline $\mathbf{X}_{\mathbf{8}}$ & & & & & & & 1 & 0,211 & $-0,130$ & $-0,389$ & $-0,351$ \\
\hline $\mathbf{X}_{\mathbf{9}}$ & & & & & & & & & 1 & $\underline{\mathbf{0 , 7 1 8}}$ & 0,059 & 0,045 \\
\hline $\mathbf{X}_{\mathbf{1 0}}$ & & & & & & & & & 1 & $\underline{\mathbf{0 , 7 3 7}}$ & $\underline{\mathbf{0 , 7 2 6}}$ \\
\hline $\mathbf{X}_{\mathbf{1 1}}$ & & & & & & & & & & 1 & $\underline{\mathbf{0 , 9 9 7}}$ \\
\hline $\mathbf{X}_{\mathbf{1 2}}$ & & & & & & & & & & & & 1 \\
\hline
\end{tabular}

Remark: : $\mathbf{X}_{1}$ - Vegetation period, $\mathbf{X}_{2}$ - Paddy yield, $\mathbf{X}_{\mathbf{3}}$ - Length of panicle, $\mathbf{X}_{\mathbf{4}}$ - Weight of a panicle, $\mathbf{X}_{5}$ - Mass of 1000 grains, $\mathbf{X}_{\mathbf{6}}$ - Total number grains in panicle, $\mathbf{X}_{\mathbf{7}}$ - Emptygrains, $\mathbf{X}_{\mathbf{8}}-$ Sterility, $\mathbf{X}_{\mathbf{9}}$ - Crude protein, $\mathbf{X}_{\mathbf{1 0}}$ Lysin, $\mathbf{X}_{\mathbf{1 1}}$ - Lysine in the protein, $\mathbf{X}_{\mathbf{1 2}}$ - Biological value of protein

Positive correlations were observed and the content of lysine in the grain, the total crude protein $(r=0.718)$, Lysine in the protein $(\mathrm{r}=0.737)$ and the biological value of the protein $(\mathrm{r}=0.726)$ and between the lysine in the protein and the biological value $(r=0.997)$. There are no significant correlations with the yield rice growing season $(r=0.509)$ and the mass of 1000 grains $(r=-0.672)$. Similar results were obtained from Ranawake (12).

Unproved negative correlation is found between the mass of 1000 grains of total grains and number of empty grains, respectively $r=-$ 0.484 and $r=-0.584$, also between the total number of grains and sterility $(r=-0.658)$, vegetation period and content crude protein $(\mathrm{r}$ $=-0.601)$. Also unproven but positive correlation was observed between the mass of 1000 grains and sterility $(r=0.693)$. Similar results were obtained in their research and Agahi,(13); Ilieva, (14); Yadav, (15).

\section{CONCLUSION}

The results indicate a low to medium variation of the studied parameters of varieties. The yield and its structural elements at the tested varieties vary to a greater extent than with the qualitative indicators.

There are established positive correlations between the total number of grains in a panicle of rice production, the weight of a panicle and the number of empty grains and negative with crude protein contents.

The positive relations exist between the content of lysine in the grain, the total crude protein, lysine in the protein and the biological value of the protein, as well as between lysine in the protein and the biological value. 
The introduced rice genotypes from Turkey and Italy in the testing period show a high degree of adaptability.

There are varieties for inclusion in the breeding programs as sources of valuable economics signs and for further scientific survey.

\section{REFERENCE}

1. Toshkov N. et al., Pysical characteristics of extrudates from rice and goji berry, Scientific works of University of food technologies - Plovdiv, vol. LXI, 444-448, 2014.

2. Muhammad A., A. Abid, G., Saddia, Response of rice (Oryza sativa L.) under elevated temperature at early growth stage: Physiological marcers. Ruusian Journal of Agrcultural and Socio - Economic Sciences, 8 (20), 11-19, 2013.

3. Shilovsky V., E. Kharitonov, A. Sheudzhen, Selection and rice varieties in the Kuban. Maikop, 34, 2001.

4. Brandon M., C. Johnson, K. Mc Kenzie, Sh. Tseng, J. Oste,: Rice breeding program. Twentieth annual report to the California rice growers, 1989.

5. Ilieva V., D. Andreevska, N. Markova, Growth and productive - technological characteristics of introduced genotypes of rice (Oryza sativa L.) in agroecological conditions of the Kocani region. Yearbook 2008, Goce Delcev University - Stip, Faculty of Agriculture, vol. 8, 27-38, 2008.

6. Baishya L., D. Sarkar, M. Ansari, N. Prakash, Yield, quality and profitability of rice (Oryza sativa L.) varieties grown in the eastern Himalayan region of India. African Journal of Agrcultural Researh, vol. 10, 1177-1183, 2015.

7. Vantsovsky A. et al., Technology of growing rice. Ukraynska Academy of Agricultural Sciences, Institute of rice, Publishers "Naddnipryanochka" 77, 2004.
TOSHEVA SV., et al.

8. Bioversity International, IRRI and WARDA, Descriptors for wild and cultivated rice (Oryza spp.). Bioversity International, Rome, Italy; International Rice Research Institute, Los Banos, Philippines; WARDA, Africa Rice Center, Cotonou, Benin., 2007.

9. Mashev N., K. Ivanov, N. Popov, P. Michailov, Handbook exercise biochemistry of plants, 72-73, Sofia, 1989.

10.Daskalov A., Variability of some major quantitative indications in rice (Oryza sativa L.). Scientific papers genetics, vol. XXXII, No. 2, 181-187, 1987.

11.Markova N., Variability of some phenotype and biochemical propreties on domestic genotype rice (Oryza sativa l.) Masters work, Goce Delchev University - Stip, Faculty of Agriculture, 126, 2010.

12.Ranawake A., G. Amarasingha, N. Dahanayake, Agronomic characters of some traditional rice (Oryza sativa L.) cultivars in Sri Lanka. Journal Univ. Ruhuna, vol. 1, №1, 3-9, 2013.

13.Agahi K., M. Fotokian, E. Farshadfar, Corelation and path coefficient analysis for some Yield - Related Traits in Rice Genotypes (Oryza sativa L.). Asian Journal of Plant Sciences, 6 (3), 513-517, 2007.

14.Ilieva V., I. Karov, N. Ruzdik, Correlation between some morphological and biochemical traits of rice (Oryza sativa L.), Scientific works of University of food technologies - Plovdiv, vol. LXI, 501-505, 2014.

15.Yadav R., B. Khatkar, B. YadavMorfological, physicochemical and cooking properties of some Indian rice (Oryza sativa L.) cultivars. Journal of Agrcultural Technology, 3 (2), 203-210 , 2007.

16.SPSS for Windows. Base System User`s Guide. Release 13, 2013. 